\title{
SEKOLAH VOKASI ILMU KOMPUTER BSD
}

\author{
Lauren Margaretha ${ }^{1)}$, Rudy Trisno ${ }^{2)}$ \\ 1)Program Studi S1 Arsitektur, Fakultas Teknik, Universitas Tarumanagara, laurenmaretha@gmail.com \\ 2) Program Studi S1 Arsitektur, Fakultas Teknik, Universitas Tarumanagara, rudyt@ft.untar.ac.id
}

\begin{abstract}
Abstrak
Pendidikan di Indonesia belum siap untuk dipakai dalam dunia kerja karena adanya keterbatasan kemampuan dari lulusan sarjana masa kini. Oleh karena itu, untuk generasi millenial sebagai calon lulusan sarjana, perubahan sistem pendidikan menjadi salah satu hal yang penting di masa depan. Secara arsitektural, hal yang ingin dicapai adalah menciptakan ruang edukasi yang sesuai dengan kebutuhan. Sekolah vokasi menjadi salah satu solusi untuk mengatasi angkatan kerja yang dianggap belum memiliki skill yang cukup. Secara spesifik, bidang yang menjadi fokus di dalam sekolah vokasi ini adalah Computer Science atau Ilmu Komputer. Teori menyimpulkan bahwa hubungan antara tipologi, arsitektur, dan perilaku millenial pada bangunan edukasi adalah ruang yang memiliki sistem kolaborasi dan ruang kelas yang efektif. Metode perancangan yang digunakan adalah analisa bertahap, yaitu pada tapak, program kegiatan, dan konsep perancangan, dimana analisa tersebut menghasilkan desain. Kesimpulannya, pemilihan tapak tidak mempengaruhi bangunan edukasi, melainkan lebih kepada pembagian sirkulasi. Pada program kegiatan, sistem bangunan secara arsitektural adalah membagi kapasitas kelas tertutup, dengan ruang terbuka seperti ruang kolaboratif untuk belajar di luar kelas ataupun saling diskusi. Program tersebut untuk membangun suasana pendidikan yang kondusif dan mendukung untuk meningkatkan kemampuan pada pelajar. Dan terakhir, ruang terbuka memiliki perbedaan peil lantai menjadi salah satu komponen dalam nilai arsitektur yang bisa digunakan untuk menjamin adanya konektivitas antar ruang.
\end{abstract}

Kata kunci: ilmu komputer; kelas kecil; konektivitas ruang; ruang kolaborasi; sekolah vokasi

\begin{abstract}
Education in Indonesia is not ready to be used in the workplace because of the limited skills of today's graduates. Therefore, for the millennium as a graduate candidate, the change in the education system is one of the important things in the future. Architecturally, what we want to achieve is to create an educational space that suits the needs. Vocational schools are one of the solutions to overcome the workforce that is considered to not have sufficient skills. Specifically, the field that is the focus of this vocational school is Computer Science or Computer Science. The theory concludes that the relationship between typology, architecture, and millennial behavior in educational buildings is a space that has an effective collaboration and classroom system. The design method used is a stepwise analysis, namely on site, program activities, and design concepts, where the analysis produces a design. In conclusion, site selection does not affect the building of education, but rather the distribution of circulation. In the activity program, the building system architecturally is to share the capacity of the closed class, with open spaces such as collaborative space to study outside the classroom or mutual discussion. The program is to build a conducive educational atmosphere and support students to improve their abilities. And finally, open space has different peil floors to be one component in architectural values that can be used to guarantee the existence of connectivity between spaces.
\end{abstract}

Keyword: collaboration space; computer science; connectivity spaces small classroom; vocational school 


\section{PENDAHULUAN}

Menurut data BPS, 8,8\% atau 618.000 sarjana masih menjadi pengangguran, sehingga bisa dikatakan sarjana masa kini yaitu mayoritas generasi millenial belum mampu menggunakan status pendidikannya untuk penerimaan lapangan pekerjaan.

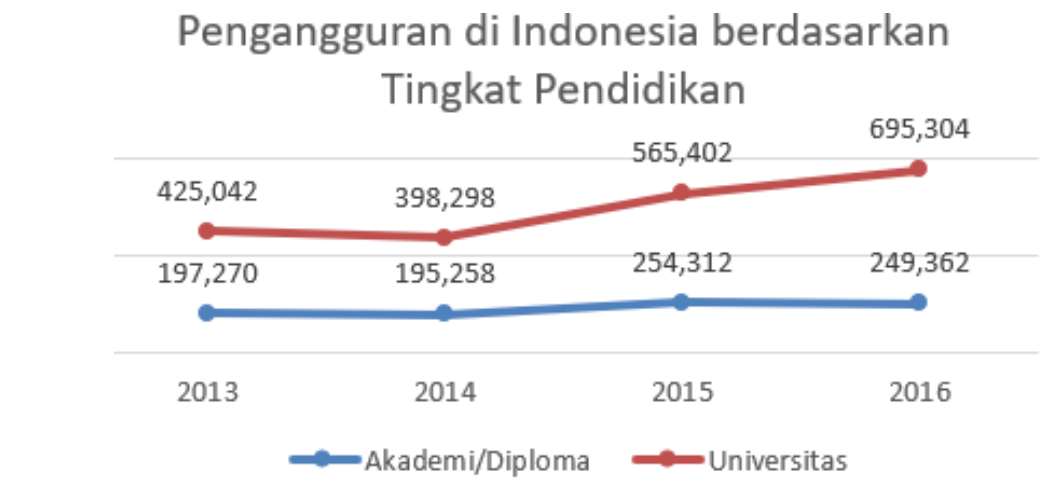

Gambar 1. Statistik Pengangguran Indonesia menurut Tingkat Pendidikan Sumber : BPS, 2017

Data dari BPS menurut artikel tanggal 15 Juli 2019, penganggur untuk universitas meningkat 25\%, dan untuk diploma naik 8,5\%. Menurut Yosepha Pusparisa, salah satu penyebabnya adalah keterampilan / skill tidak sesuai kebutuhan. (Pusparisa, 2019)

Setelah melihat fakta tersebut, Indonesia perlu memperbaiki dan mendesain ulang sistem dan konsep dari perguruan tinggi sehingga bisa diterima dengan baik di dunia pekerjaan, seperti pemilihan antara sistem empat tahun kuliah atau pelatihan sertifikat internasional yang hanya memakan waktu enam bulan. Sistem pendidikan tersebut sudah banyak digunakan oleh negara lain dalam hal membentuk skill pelajar untuk siap kerja. Skill yang dibutukan di dalam dunia pekerjaan di antaranya Leadership skills, Teamwork skills, Verbal Communication skills, Problem solving skills, dan lain sebagainya.

Beberapa skill seperti yang disebutkan di atas dibutuhkan di dalam dunia kerja saat ini sehingga membutuhkan banyak perhatian pada bidang selain akademik, karena tidak akan membuat pelajar menjadi berkembang dan kreativitas serta bakat mereka tidak dapat terinpretasikan dengan baik, dan tidak akan memberikan keuntungan. Dari permasalahan yang ada, sekolah vokasi dipilih karena itu sistem pendidikan yang sudah digunakan oleh pendidikan luar negeri untuk menghasilkan lulusan yang dapat diterima di lapangan pekerjaan.

Peran arsitektur sangat perlu diperhatikan, dimana perlu meninjau kembali bagaimana tipologi edukasi yang sesuai untuk mengatasi permasalahan tersebut. Arsitektur edukasi perlu dikaji kembali dengan melihat bagaimana perilaku manusia yang ada, khususnya generasi millennial.

Oleh karena itu, proyek ini berfokus untuk mencari solusi desain dengan dari beberapa perumusan masalah, yaitu perumusan cara membangun sebuah tempat edukasi yang sesuai dengan perkembangan di zaman milenial ini, dan hal yang penting tersebut adalah pengembangan diri, baik ilmu pengetahuan yang terus maju dengan adanya pelatihan yang interaktif, dan juga mengenai permasalahan tersebut menjadi sebuah pemikiran sehingga pada akhirnya harus memikirkan solusi secara arsitektural, yaitu bagaimana tata letak ruang, baik dalam bentuk ruangan (fisik) ataupun ruang (nonfisik/spatial), sehingga proyek edukasi ini memberikan suasana yang kondusif dan berkualitas untuk melakukan kegiatan belajarmengajar.

Desain ini dibuatkan dengan tujuan / visi sebagai berikut, yaitu, memberikan edukasi yang digital learning-based dan berkaitan dengan eksplorasi diri, menciptakan suasana belajar yang santai namun tetap kondusif dan menciptakan sebuah komunitas di dalam tempat edukasi yang saling berkolaborasi. Untuk mencapai beberapa visi tersebut, maka hal-hal yang perlu dilakukan supaya dapat terealisasikan secara arsitektural adalah : 
a. Memperhatikan sirkulasi dan hubungan antar ruang yang secara tidak langsung mempengaruhi bagaimana penghuni bangunan berperilaku.

b. Mengurangi sistem classroom yang tertutup dan berkapasitas terlalu besar, dan lebih memperlihatkan keterbukaan dan sistem kelompok kecil pada pengalaman ruangnya

c. Membuat ruang untuk berkolaborasi untuk pelajar, yaitu ruang bersama

d. Mendesain sebuah ruang publik yang terbuka sehingga dapat diterima oleh semua kalangan masyarakat dan kalangan sendiri.

e. Dalam mendesain interior ruangan, harus memikirkan adanya media digital yang menjadi connector untuk pelajar menimba ilmunya, dan guru/dosen melakukan bimbingan.

Dengan lokasi proyek yang terletak di BSD, kota satelit yang sedang mengalami perkembangan, sumbangan dari proyek yang bisa diberikan untuk kehidupan di kota Tangerang tersebut berupa:

- Peningkatan kualitas pendidikan bagi masyarakat setempat yang sesuai dengan perkembangan jaman, khususnya literasi teknologi dan basic skill untuk dunia pekerjaan

- Menjadi perantara bagi perusahaan di Tangerang atau luar Tangerang dalam hal rekutmen pekerja ataupun training.

- Koneksi antara fasilitas pendidikan yang lain bisa melibatkan kerja sama untuk melakukan event, program bersama

- Mengurangi pengangguran bagi sarjana yang belum mendapatkan sarjana (dalam jangka yang panjang)

\section{KAJIAN LITERATUR}

Material

\section{Sekolah Tinggi}

Menurut Kamus Umum Bahasa Indonesia, definisi sekolah tinggi adalah lembaga yang memberikan pembelajaran setingkat pendidikan tinggi atau setelah pendidikan menengah ke atas. Menurut Peraturan Pemerintah RI no. 30 mengenai Pendidikan Tinggi, adalah pendidikan memberikan nilai akademik dan melatih profesionalitas dalam lingkup tertentu.

Berikut ini Keputusan Menteri Pendidikan Nasional nomot 234/U/2000 tanggal 20 Desember 2000 mengenai persyaratan pengadaan sekolah tinggi dan politeknik:

Tabel 1. Persyaratan minimal sarana dan prasarana

\begin{tabular}{lcc}
\hline Sarana dan Prasarana & Politeknik & Sekolah Tinggi \\
\hline Ruang Kuliah & $300 \mathrm{~m}^{2}$ & $200 \mathrm{~m}^{2}$ \\
\hline Ruang Kantor Administrasi & $40 \mathrm{~m}^{2}$ & $30 \mathrm{~m}^{2}$ \\
\hline Ruang Perpustakaan & $300 \mathrm{~m}^{2}$ & $200 \mathrm{~m}^{2}$ \\
\hline Ruang Komputer & $360 \mathrm{~m}^{2}$ & $270 \mathrm{~m}^{2}$ \\
\hline Ruang Labotarium & $400 \mathrm{~m}^{2}$ & $300 \mathrm{~m}^{2}$ \\
\hline Ruang Dosen Tetap & $90 \mathrm{~m}^{2}$ & $60 \mathrm{~m}^{2}$ \\
\hline Tanah & $5.000 \mathrm{~m}^{2}$ & $5.000 \mathrm{~m}^{2}$ \\
\hline
\end{tabular}

Sumber : (Kurnianto, 2009)

Ilmu Komputer (Computer Science)

Bidang ilmu komputer sebagai materi pendidikan yang dijalankan di dalam proyek ini memiliki kurikulum yang disesuaikan dengan ketentuan Pendidikan Nasional maupun sekolah tinggi di luar negeri. Dalam hal ini, kurikulum yang digunakan sebagai standar adalah ACM (Association for Computing Machineries). Di dalam kurikulum tersebut, ilmu computer bersifat holistik, teknis dan berbasis pada soft skills, dan memberikan pelatihan karakter ( (ACM \& IEEE, 2013) 


\section{Vokasi}

Kurikulum yang digunakan menggunakan dual system 3-2-1, yaitu belajar di dalam kampus selama tiga (3) semester, dilanjutkan dengan dua (2) semester magang di industri dan diakhiri dengan satu (1) semester untuk menyelesaikan pendidikan di kampus atau di industri. Mata kuliah pendidikan vokasi meliputi:
a. Teori
b. Praktikum
c. Workshop
d. Kerja praktek lapangan (On the Job Training)
e. Proyek akhir ( (Direktorat Jenderal Pembelajaran dan Kemahasiswaan, 2016)

Teori

Arsitektur

Menurut Britannica, arsitektur adalah seni dan teknik mendesain dan menjadikan bangunan dapat dikenal dari kemampuan yang terhubung dengan konstruksi. Untuk mendefinisikan 'arsitektur', dua hal yang perhatikan adalah praktikal dan unsur yang bermakna, dan hasilnya memiliki nilai utilitas dan keindahan yang seimbang. Untuk fungsi yang lebih spesifik ke arah edukasi, sisi arsitekturnya berawal pada pengaruh dari abad pertengahan, dimana konsep perancangan tersebut masih terlihat pada Universitas Oxford, Cambridge dan Paris, namun setelahnya, mulai ada perubahan karena ada spesialisasi dari arsitektur tertentu, seperti adanya penggunaan pusat penelitian, pelatihan untuk profesi dan dagang, dan lainnya.

\section{Arsitektur dan Edukasi}

Adanya berbagai jenis latar belakang masyarakat, baik yang sudah berkembang pesat ataupun kurang, hidup menetap atau nomaden, semuanya memiliki hubungan spasial dengan alam luar dan masyarakat lainnya dan arsitektur menjadi seperti cerminan dari manusia di dalamnya.

Permasalahan mulai muncul pada edukasi di dalam masyarakat saat cara mengajar kepada pelajar menjadi pasif dan tidak bisa memunculkan kreaktivitas. Padahal seharusnya, cara belajar yang dianggap lebih sesuai dengan cara membuat alternatif dari social control dari sekolah. Institusi yang baru diharapkan memperlihatkan bahwa edukasi tidak bisa diterima secara berbeda-beda oleh kalangan tertentu, melainkan lebih terbuka. (Alexander, Ishikawa, \& Silverstein, 1977)

Di dalam bukunya, 'A Pattern Language', menjelaskan bahwa edukasi kini mulai berubah menjadi lebih menyebar / tidak terpusat. Melakukan eksplorasi untuk belajar adalah hal yang bisa dilakukan untuk meningkatkan kemampuan lebih dibandingkan belajar di satu tempat saja, seperti workshop, jalan-jalan mengelilingi kota, pergi ke museum, seminar.

\section{Tipologi Edukasi}

Secara arsitektural, tipologi dapat didefinisikan sebagai konsep dimana ada pemilahan sifat objek berdasarkan kesamaan sifat, sehingga ada pengelompokan unsur-unsur. (Ching, 1979). Merancang bangunan berdasarkan program dianggap tidak cukup untuk merangkum seluruh kegiatan yang ada, dimana tipe seharusnya mendukung penyelesaian perancangan desain. (Colquhoun, 1996)

Menurut Christian Kuhn, tipologi pada edukasi memiliki beberapa perkembangan, mulai dari perbedaan ruang antara gender, bentuk classroom yang terdiri dari barisan, dan setting itu dibuat di masa Revolusi Industri, untuk menunjang ekonomi, dan ironisnya, sampai sekarang setting ruang kelas tersebut masih dipakai, walaupun sudah tidak terlalu mencekam dan ada kesetaraan gender, namun ruangnya masih memiliki kesan 'terkontrol'. 


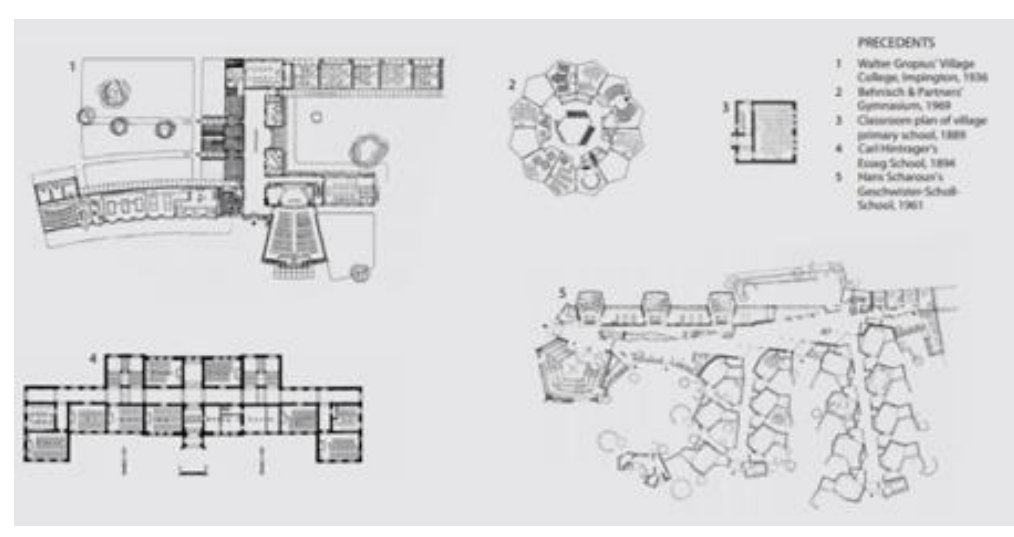

Gambar 2. Contoh Tipologi Sekolah Sumber: The Architectural Review

Bangunan sekolah seharusnya merespon beberapa kebutuhan masyarakat yang sudah berubah. Tidak melihat kepada tipologi yang lama, namun melihat sesuatu yang lebih bervariasi daripada model yang sederhana dan umum. Hal-hal yang perlu diperhatikan adalah :

- Fleksibilitas

- Ruang di dalam sekolah yang didistribusikan menjadi kelompok yang lebih kecil.

- Pengadaan area untuk tempat bertemu yang informal, yang menjadi gagasan dari konektivitas. (Kuhn, 2012)

Perilaku

Perilaku yang sering dilakukan memberikan dampak dua arah. Artinya adalah hal yang mempengaruhi adanya kondisi sebuah lingkungan, namun, lingkungan juga bisa memberikan dampak pada perilaku setiap individu. Di dalam bidang keilmuan, perilaku dipelajari sebagai behaviorisme. Secara definisi, perilaku adalah aktivitas fisik dan interaksi manusia di dalam lingkungan. (Tandal \& Egam, 2011)

Perilaku dipengaruhi oleh faktor eksternal dan internal. Faktor tersebut mempengaruhi respon lingkungan, sehingga arsitek perlu melakukan studi lebih lanjut mengenai hubungan behaviorisme dcngan arsitektur. Faktor-faktor yang menentukan tersebut ialah:

- Faktor internal : berasal dari dalam diri, seperti kecerdasan, tingkat emosional, jenis kelamin, spiritualitas, dll.

- Faktor eksternal : lingkungan fisik, ekonomi, politik, dll.

Di antara keduanya, faktor eksternal lebih memberi pengaruh pada perilaku seseorang, sehingga latar belakang seseorang yang berbeda-beda memberikan banyak perbedaan pada satu sama lain.

\section{Generasi Millenial}

Secara definitif, generasi millenial adalah generasi yang lahir pada tahun 1981 -2000. Generasi yang menduduki jumlah populasi terbanyak di dunia ini dianggap adalah generasi yang memberikan banyak perubahan terhadap segala hal di dunia, dan yang paling berubah adalah munculnya teknologi digital.

Generasi Millenial atau Generasi Y banyak menggunakan teknologi untuk berkomunikasi secara instan melalui media sosial seperti Twitter, email, SMS, Instagram, Facebook, dan lainnya. Selain untuk berkomunikasi, media sosial juga menjadi tempat para pengguna untuk memperlihatkan eksistensinya, dimana jika berlebihan, pengguna tersebut disebut memiliki sifat narsistik. 
Meskipun generasi millenial tumbuh dalam teknologi yang sudah berkembang pesat ini, tetapi karakteristik tiap individu juga bergantung pada tempat lahir, tingkat ekonomi, nilai sosial dan budaya keluarga dan lingkungannya, pola komunikasi yang terbuka atau tertutup. (Lyons, 2003)

Hubungan antara Arsitektur, Tipe, Perilaku, dengan nilai kesejamanan.

Dari teori di atas, hal yang dapat disimpulkan adalah :

1. Tipologi edukasi yang terbentuk akan menentukan bagaimana penataan ruang belajar dan bentuk bangunan edukasi yang dihasilkan sesuai kebutuhan pada masa tertentu.

2. Perilaku dalam dunia edukasi memberikan dampak pada berbagai aspek, seperti aspek psikologis pada individu antara kegiatan belajar masa lalu yang terpaku pada aturan dengan masa kini yang lebih fokus kepada kebutuhan pelajar dalam meningkatkan potensi dirinya.

3. Generasi millennial di dunia edukasi akan memberikan perbedaan pada masa sebelumnya, dalam hal menanggapi ilmu serta mengeksplorasinya sendiri dengan media berupa teknologi digital, sehingga untuk hasil yang diterima adalah mengkondisikan fungsi edukasi yang sesuai dengan karakteristik dari generasi millennial dalam bentuk ruang dan arsitektural.

\section{METODE PERANCANGAN}

Dari kesimpulan di atas, indikator yang dapat digunakan adalah dengan menyesuaikan tipologi edukasi (pendidikan vokasi) yang ada dan mengidentifikasi masalah menggunakan pola deskriptif analisis. Metode ini berupa pemaparan atau deskripsi dari kondisi riil dengan literatur-literatur yang menjadi teori-teori untuk mendukung proyek yang dikerjakan. Analisa data dilakukan secara kualitatif, yaitu data-data dan teori yang bersangkutan diolah dengan proses analisa, untuk menghasilkan sebuah rancangan baru.

Untuk metode pengumpulan data primer, dilakukan observasi, baik secara fisik dengan nonfisik (perilaku generasi millennial di Indonesia). Sedangkan untuk data sekundernya, khususnya untuk statistik perilaku menggunakan studi literatur. Untuk studi preseden, beberapa hal yang perlu dianalisis adalah program secara detail, bagaimana desain dari preseden-preseden yang sebelumnya bisa menjawab berbagai kondisi, dan juga sistem programming di dalamnya.

Berikut ini tahap analisa yang dilakukan untuk melakukan perancangan:

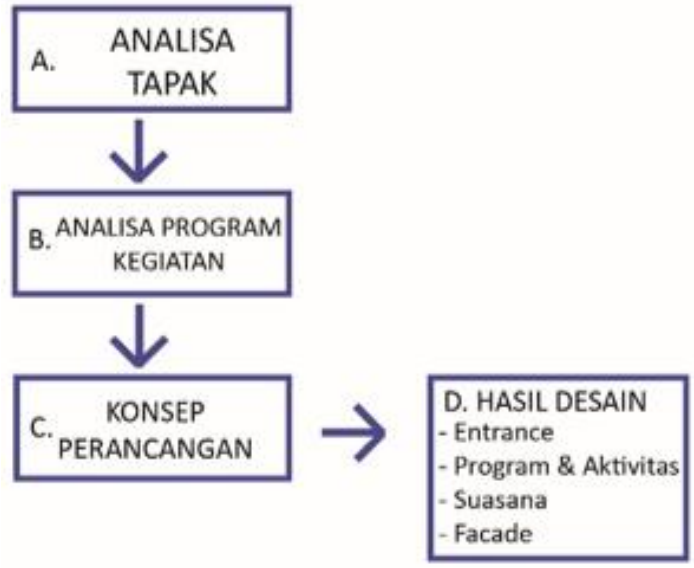

Gambar 3. Metode Perancangan

Sumber : Penulis, 2019 


\section{DISKUSI DAN HASIL}

\section{Analisa Tapak Bangunan}

Berlokasi di BSD, Serpong, Tangerang yang berbatasan dengan Gading Serpong dan Cisauk, masih banyak peluang yang ada untuk menambah fungsi-fungsi yang ada.yang menjadi tapak untuk proyek ini, memiliki banyak lahan bebas yang belum diisi oleh bangunan lain di sekitarnya.

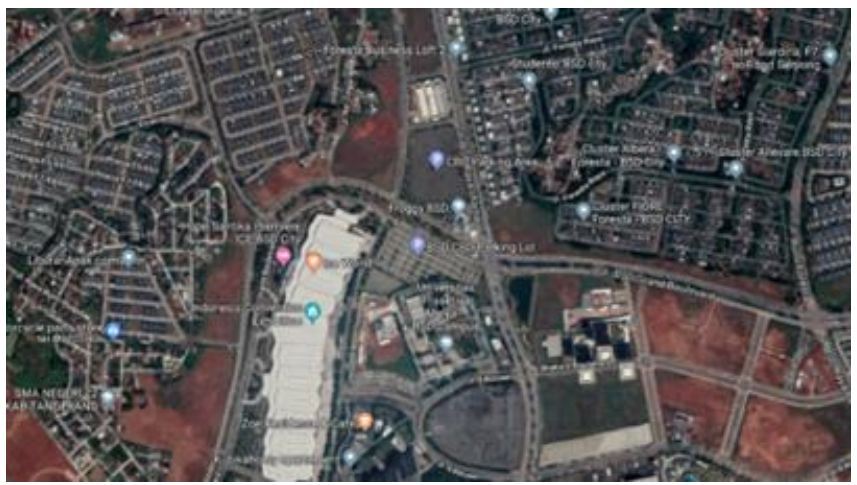

Gambar 4. Peta Makro Tapak

Sumber: Google Map

Berada di zona Pendidikan, tapak memiliki kelebihan tersendiri karena dengan melihat fungsinya, proyek bisa melakukan kerja sama dan lintas ilmu dengan fungsi di sekitar, yaitu ICE BSD dan Universitas Prasetiya Mulya. Secara area makro yang lebih luas, jalan memiliki tingkat mobilitas yang cukup tinggi, dimana banyak orang yang berdatangan ke bangunan komersil sekitar, seperti AEON Mall, The Breeze, Qbig, dan lainnya. Walaupun berada di area yang lebih didominasi oleh kendaraan pribadi, namun jalan akses ke tapak adalah jalan lingkungan yang nama jalannya pun tidak diketahui, dan aktivitas yang melewati jalan tersebut belum banyak, sehingga kemacetan tidak sering terjadi di sekitar tapak.

Banyaknya lahan kosong memungkinkan untuk para pengguna bangunan menjadi merasa lebih tenang, dibandingkan dengan kepadatan yang tinggi dan menempatkan tempat edukasi di tengahnya, sehingga aktivitas yang dilakukan bisa lebih efektif.

Dengan melihat dari rencana untuk kedepannya, akan ada rencana jalan tol, dan pembangunan SCBD yang semakin menunjang aktivitas di sekitar tapak, sehingga secara tidak langsung area BSD memiliki mobilitas yang lebih tinggi dan aksesbilitas dari luar kota menjadi lebih mudah. Lebih mudah untuk mendapatkan orang karena akses tol yang ada akan menjadi nilai penting bagi pengguna untuk memilih tempat edukasinya.

\section{Analisa Program Kegiatan}

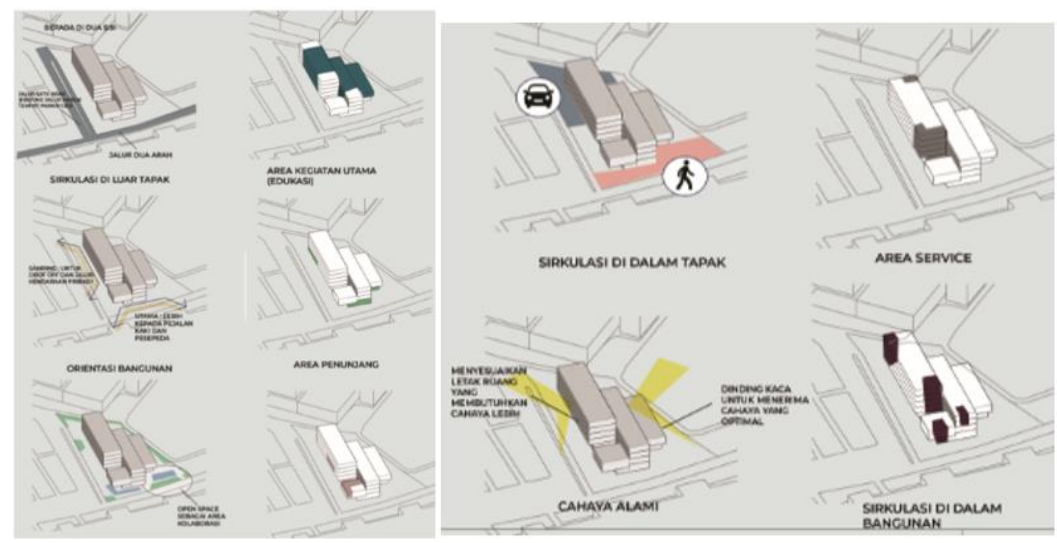

Gambar 5. Design Scheme

Sumber : Penulis, 2019 
Dengan adanya perbedaan sistem antara edukasi berbasis akademik dengan basis praktikal, maka kapasitas kelas dan laboratorium mempunyai beberapa perbedaan. Berdasarkan analisa dari studi mengenai program studi dari politeknik (memiliki kurikulum yang sama dengan sekolah Vokasi) lain dengan mata kuliah yang harus digenapi di dalam jurusan-jurusan Computer Science, maka kebutuhannya adalah sebagai berikut:

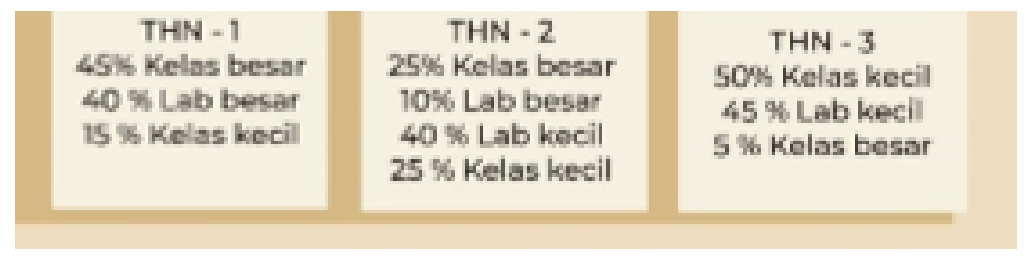

Gambar 6. Persentase Ruang Utama

Sumber : Penulis, 2019

Dari beberapa kapasitas di dalamnya, program ruang yang didapatkan adalah persentase dengan area aktivitas utama sebanyak $70 \%$, fasilitas penunjang sebanyak $15 \%$, fasilitas pengelola sebanyak $10 \%$ dan area servis sebanyak $5 \%$.

Di dalam program ruang utama pun terbagi-bagi menjadi beberapa bagian:

- Open Classroom / Ruang bersama

- Lecture Room / Auditorium

- Library

- Kelas dan Lab

\section{Konsep Perancangan}

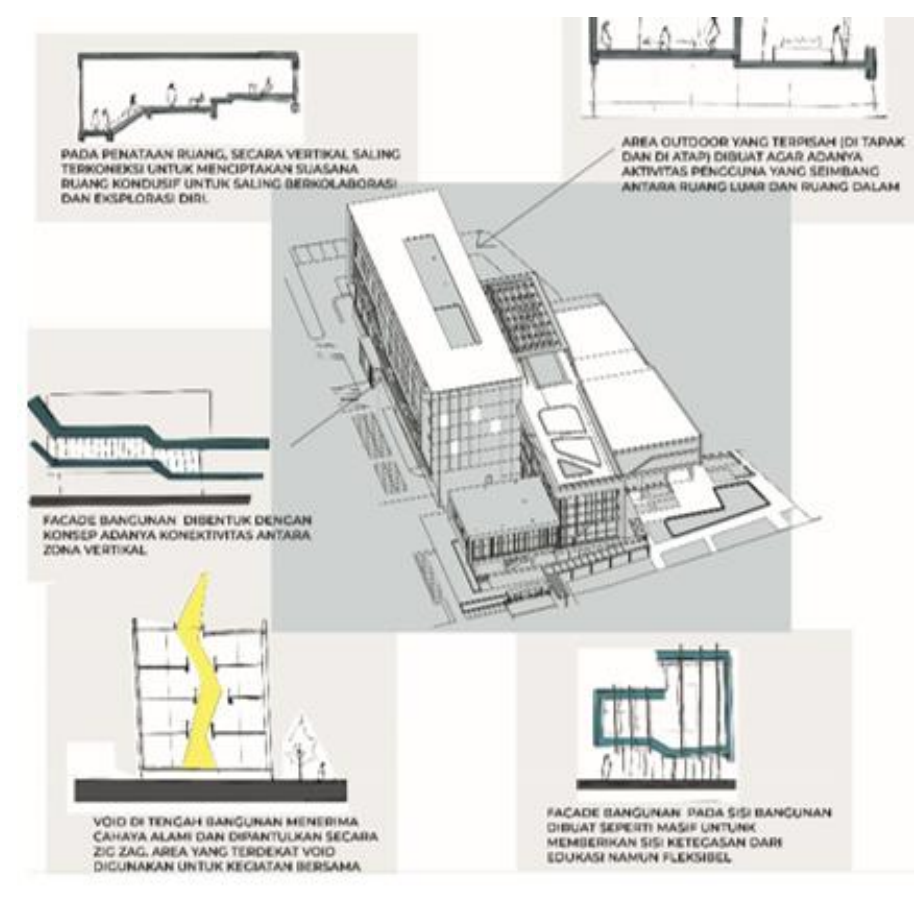

Gambar 7. Konsep Bangunan

Sumber : Penulis, 2019 
Konsep yang ingin didesain di dalam bangunan adalah sistem sebagai berikut :
a. social, community, \& collaboration
b. Openess, Transparance
c. Edukasi berbasis Digital
d. Praktikal lebih daripada Teoritikal

Tema yang diambil dari berbagai analisa yang ada menggabungkan sistem high-tech technology yang bersifat privat dan tertutup dengan adanya eksplorasi diri, sehingga hal yang jelas terlihat adalah bagaimana pembagian ruangnya yang lebih banyak melakukan aktivitas di dalam ruangan.

Teknologi digital yang didorong untuk menjadi media dalam pembelajaran, maka perlu adanya beberapa sistem yang di dalam desain dan secara arsitektural bisa diterapkan:

- Blended Learning

- Flipped Classroom

- Collaborative Space

Sistem belajar yang dijadikan sebagai standar untuk menciptakan lingkungan belajar yang lebih baik saya terapkan di dalam proyek ini, dimana pelajar yang menjadi target ini bisa lebih fokus kepada student-centered learning daripada teacher-centered learning.

Adanya penggabungan antara sistem yang berbeda memunculkan adanya sistem di dalamnya ketika ada konektivitas antara kegiatan, namun tetap menjaga adanya kualitas individualitas, sehingga tidak ada yang menjadi bias antara keduanya.

Selain konektivitas, cahaya juga penting pada proyek ini.Berkaitan dengan area yang saling terkoneksi, cahaya alami secara tidak langsung juga akan saling tersambung dari skylight sampai lantai dasar. Kegiatan yang berada di dalamnya lebih ke arah keterbukaan sehingga alur sirkulasi tidak terganggu oleh pemisahan dinding.

\section{Hasil Desain}

\section{Entrance}

Karena bangunan edukasi lebih berfokus kepada sirkulasi pelajar yang lebih banyak dibandingkan kendaraan, maka ada perbedaan dengan prioritas antara pejalan kaki dengan sirkulasi mobil/motor dan diusahakan untuk tidak terjadi adanya cross/pertemuan antar jalur keduanya.

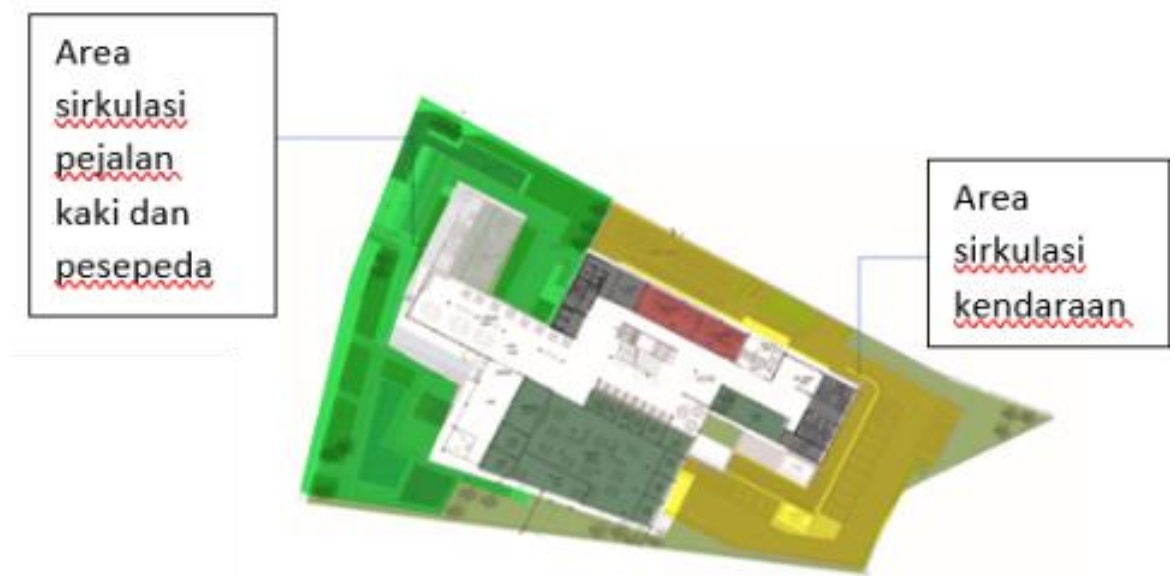

Gambar 8. Entrance Bangunan

Sumber : Penulis, 2019

Oleh karena itu, dengan adanya pembagian sirkulasi, terdapat dua entrance bangunan, yaitu main entrance yang berada di dekat jalan utama dan dapat dijangkau untuk sirkulasi pejalan kaki / pesepeda, dan juga adanya side entrance yang berada di sisi tapak bangunan 
yang berdekatan dengan. jalur eksisting kendaraan untuk tempat parkir mobil CBD BSD. Di dalam tapak, antara main entrance dan side entrance tidak ada bentrokan satu sama lain.

\section{Pembagian Zona dan Tatanan Ruang}

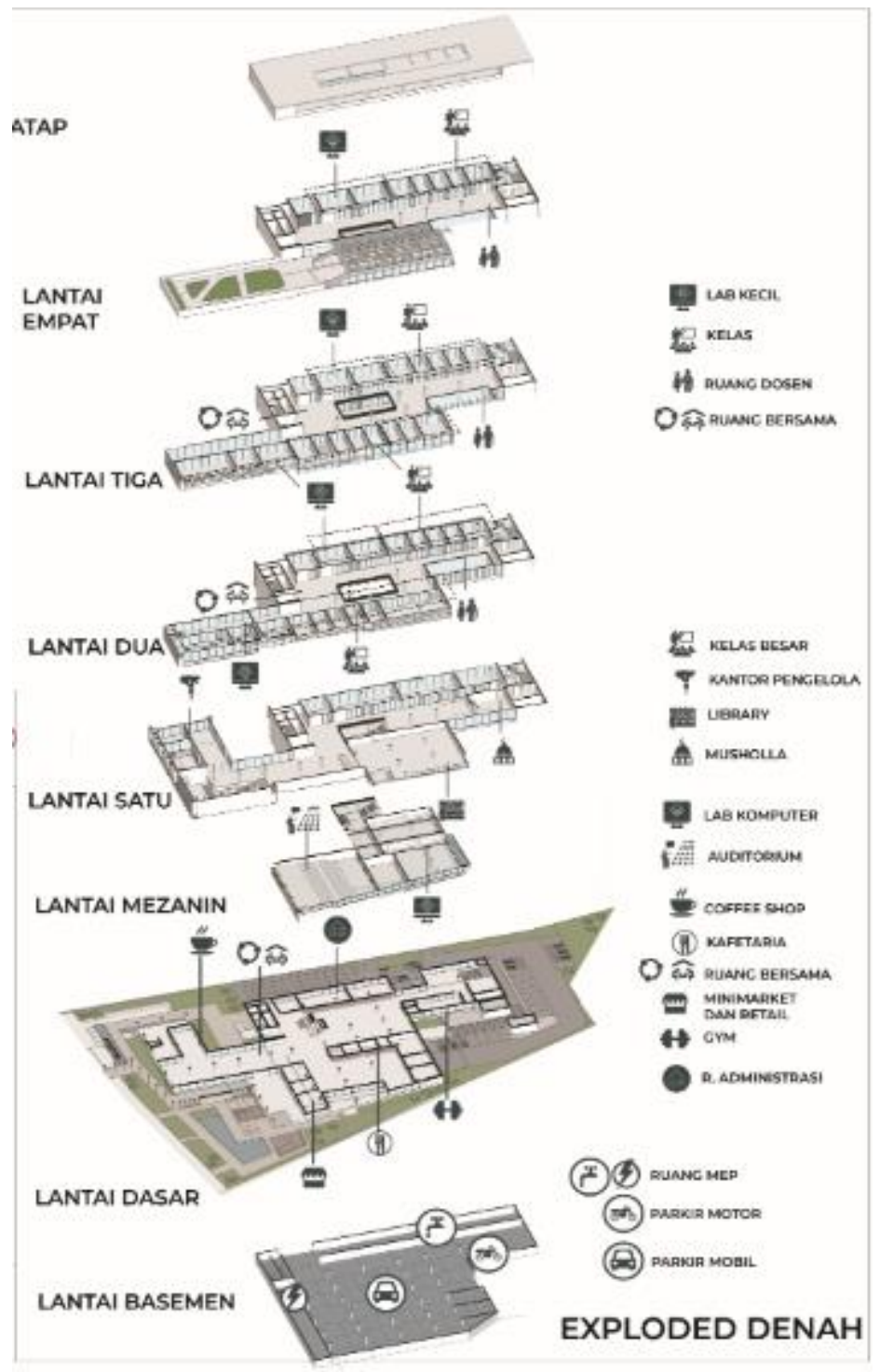

Gambar 9. Denah

Sumber : Penulis, 2019

Di lantai dasar, untuk pembagian zonanya terdapat area penunjang, dan juga dengan area terdekat dengan side entrance terdapat ruang administrasi untuk kebutuhan registrasi dan lainnya. Lantai dasar dibuat tertutup (adanya pintu otomatis dan semua ruang berada di dalam bangunan) dikarenakan dibutuhkan sistem keamanan yang cukup untuk perangkat komputer yang berada di dalam bangunan.

Di lantai satu memuat area dimana ada aktivitas kelas yang digunakan untuk tahap semester awal, dimana mata kuliah antara program studi dapat dijalankan secara bersamasama, sehingga membutuhkan kapasitas yang besar, sedangkan di lantai dua dan tiga, mulai ada tatanan ruang yang lebih fokus kepada ruang-ruang yang dengan program studi yang lebih spesifik dan kecil. Hal ini dilakukan sebagai upaya untuk menciptakan ruang belajar dengan kondisi yang lebih efektif dalam menyerap ilmu bagi pelajar dan interaksi antara pelajar serta pengajar/dosen menjadi lebih baik. 


\section{Suasana Ruang dan Aktivitas}
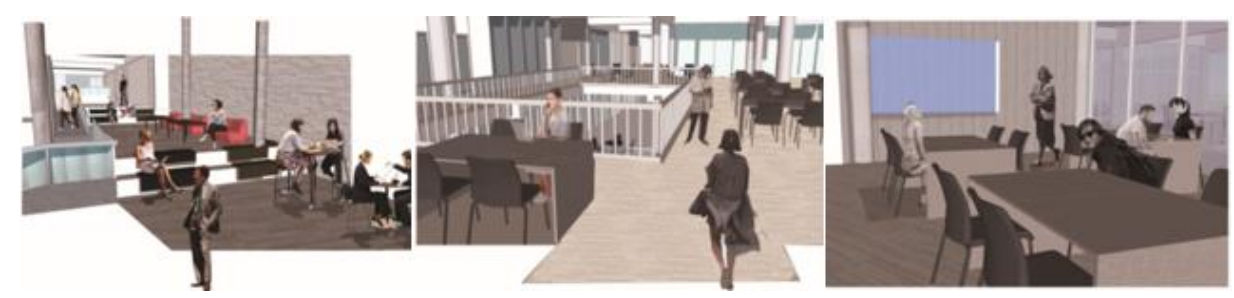

Gambar 10. Interior Area Bersama 1\&2 dan Interior Ruang Kelas

Sumber : Penulis, 2019

Dengan adanya peletakan ruang yang berfokus kepada konektivitas antara lantai dan mezanin, aktivitas yang diharapkan di dalamnya saling berkelanjutan antara Bersama dengan ruang kelas yang tertutup. Perbedaan elevasi yang kecil namun bertahap digunakan pada area bersama 1 diatasi dengan penambahan aktivitas seperti area duduk yang berundak untuk pelajar melakukan aktivitas individual ataupun Bersama, dan juga dengan ramp untuk sirkulasi vertikal.

Area Bersama yang terhubung pada void memiliki koneksi pada lantai di atas atau di bawahnya, sehingga hal yang dimaksudkan seperti perbedaan program studi pun tidak menjadi penghalang adanya kolaborasi antar pelajar. Selain untuk aktivitas, void yang dibuka juga dimanfaatkan untuk menerima cahaya matahari secara langsung.

Kelas dengan kapasitas kecil menjadikan aktivitas seperti diskusi dan saling bertukar ilmu menjadi lebih efektif dalam hal menambah skill bagi pelajar.

Fasade Bangunan

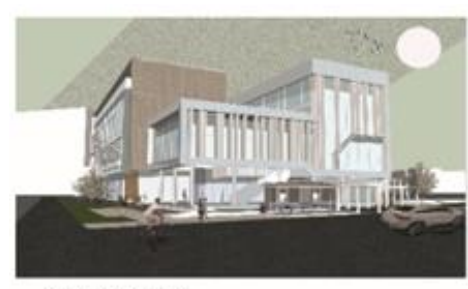

TAMPAK DEPAN

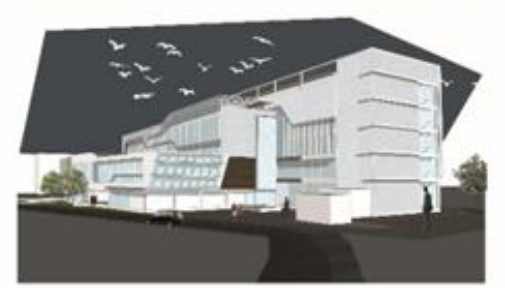

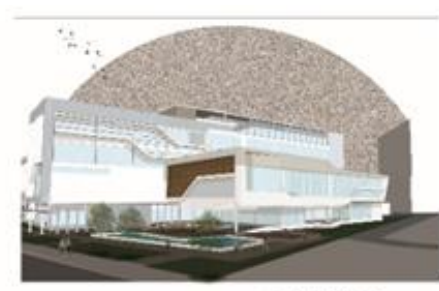

AREA RUANG PUBLIK

Gambar 12. Eksterior bangunan

Sumber : Penulis, 2019

Secara massa bangunan, bentuk bangunannya kotak dengan ketegasan yang terlihat Massa secara tidak langsung terbagi menjadi empat bagian.

Desain perancangan secara arsitektural menempatkan façade menjadi salah satu poin yang mempengaruhi tema dari bangunan itu, dimana unsur kemiringan menjadi ciri khas utama dari tampak bangunan, dimana mencerminkan bahwa setiap peil lantai yang berbeda dapat terkoneksi dengan baik sehingga memunculkan kesan saling terikat dan bersama. Beberapa unsur seperti kemiringan yang ditambahkan ke bangunan menjadi salah satu bagian yang penting dalam desain. Untuk material sebagian besar menggunakan dinding kaca serta second skin ACP. 


\section{KESIMPULAN DAN SARAN}

\section{Kesimpulan}

Dari beberapa bagian yang dibahas, dari Arsitektur, Tipe, dan Perilaku, semuanya saling berkaitan dan akan selalu memberikan dampak, khususnya untuk bagi bangunan edukasi. Secara arsitektural, untuk membuat bangunan edukasi yang sesuai dengan generasi millenial, dapat disimpulkan bahwa:

- Lokasi tapak tidak mempunyai pengaruh besar dengan program edukasi, dimana pengguna bangunan yaitu pelajar sendiri lah yang lebih banyak menyesuaikan diri dengan tapak.

- Pengolahan entrance yang terpisah menjadi peran penting untuk menciptakan aktivitas bersama yang ideal di luar ruangan.

- Penataan ruang untuk sekolah vokasi yang sesuai untuk generasi millennial adalah ruang yang ditata dengan memperhatikan rasio antara ruang terbuka dan tertutup yang seimbang, sehingga komendisi ruang yang diharapkan untuk pelajar pun mendukung adanya peningkatan kualitas diri.

- Ruang terbuka yang memiliki perbedaan peil lantai menjadi salah satu komponen dalam nilai arsitektur yang bisa digunakan untuk menjamin suasanan kondusif dengan adanya konektivitas antar ruang.

\section{Saran}

Secara pengolahan program juga diharapkan agar di dalam bangunan edukasi memberikan upaya bahwa kegiatan praktek khususnya simulasi menjadi bagian penting yang seharusnya lebih mendominasi dibandingkan dengan teori, sehingga, tidak hanya pendidikan vokasi saja yang menerapkan, melainkan juga sistem pendidikan yang lain.

\section{REFERENSI}

ACM \& IEEE. (2013). Computer Science Curricula 2013 : Curriculum Guidelines for Undergraduate Degree Program in Computer Science. Amerika Serikat: ACM \& IEEE Computer Society.

Alexander, C., Ishikawa, S., \& Silverstein, M. (1977). A Pattern Language : Towns, Building, Construction. New York: Oxford University Press.

Ching, F. D. (1979). Architecture Form, Space, and Order. New York: Van Nostrand Reinhold.

Colquhoun, A. (1996). Typology and Design Method. Theorizing Architecture for Architecture: an Anthology of Architectural Theory, 250-257.

Direktorat Jenderal Pembelajaran dan Kemahasiswaan. (2016). Panduan Penyusunan Kurikulum Pendidikan Vokasi. Jakarta: Kementrian Riset Teknologi dan Pendidikan Tinggi.

Keputusan Menteri Pendidikan Nasional Republik Indonesia nomor 234/U/2000 tentang Pedoman Pendirian Perguruan Tinggi

Kuhn, C. (2012, March 29). Typology : School. The Architectural Review.

Kurnianto, K. H. (2009). Sekolah Tinggi Arsitektur di Kota Malang dengan Tema Arsitektur Tropis. Malang: ITN.

Lyons, S. (2003). An Exploration of Generational Values in Life and at Work. Ottawa: Carieton University.

Pusparisa, Y. (2019). Angka Pengangguran Lulusan Universitas Meningkat. Retrieved May 17, 2019, from https://katadata.co.id/infografik/2019/05/17/angka-pengangguran-lulusanperguruan-tinggi-meningkat

Tandal, A. N., \& Egam, I. P. (2011). Deskripsi umum behaviorisme. Arsitektur Berwawasan Perilaku (Behaviorisme), 53-54. 